\author{
Iwona D. Czechowska \\ Uniwersytet Łódzki
}

\title{
ETYKA W BANKOWOŚCI W ODNIESIENIU DO WSPÓŁPRACY Z SEKTOREM UBEZPIECZENIOWYM
}

Konsumenci, ich zachowania na rynku, przesłanki działania, dokonywane wybory pełnią bardzo ważną rolę dla funkcjonowania i rozwoju gospodarki. Jednak bywa często, że traktowani są instrumentalnie przez profesjonalnych usługodawców. Mając na uwadze dominację sektora bankowego na rynku pośrednictwa finansowego oraz znaczenie konsumentów, jako istotnej grupy klientów tego sektora, w niniejszym opracowaniu starano się przedstawić problematykę systemu ochrony konsumentów na rynku usług bankowych powiązanych z ubezpieczeniowymi, w odniesieniu do kredytów hipotecznych, z uwzględnieniem zagadnień etycznych. Powyższa tematyka jest rozległa, wielowątkowa, aktualna oraz wzbudza emocje.

\section{Miejsce sektora bankowego w systemie finansowym}

Przed przedstawieniem zagadnień etycznych związanych z bankowością, w celu zrozumienia istoty problemu trzeba zaprezentować ważną pozycję sektora bankowego w systemie finansowym. Analizując system finansowy możemy zaobserwować tendencję polegającą na powiększaniu relacji aktywów światowego systemu finansowego w stosunku do PKB, poza okresem 2000-2002 oraz rokiem 2008, w którym miał miejsce kryzys na rynkach finansowych. Od roku $2001 \mathrm{w}$ systemie finansowym dominuje pod względem wielkości aktywów sektor bankowy a następnie rynek akcji (zob. tab. 1).

Tendencję wzrostu systemu finansowego można również zaobserwować w gospodarkach krajów Europy Środkowo-Wschodniej m. in. w Polsce, przy czym relacja aktywów systemu finansowego do PKB jest najniższa w porównaniu do Czech i Węgier i o kilkukrotnie niższa niż w strefie euro (zob. tab. 2). 
Aktywa światowego systemu finansowego w latach 2000-2008

\begin{tabular}{|l|r|r|r|r|r|r|r|r|c|}
\hline Lata & 2000 & 2001 & 2002 & 2003 & 2004 & 2005 & 2006 & 2007 & 2008 \\
\hline Nominalny PKB (w bln USD) & 37 & 39 & 40 & 42 & 46 & 49 & 52 & 57 & 61 \\
\hline $\begin{array}{l}\text { Aktywa systemu finansowego } \\
\text { do PKB (w \%) }\end{array}$ & 303 & 297 & 282 & 298 & 305 & 320 & 334 & 343 & 293 \\
\hline Rynek akcji (w bln USD) & 37 & 33 & 26 & 33 & 38 & 45 & 54 & 62 & 34 \\
\hline $\begin{array}{l}\text { Papiery dłużne sektora publicz- } \\
\text { nego (w bln USD) }\end{array}$ & 17 & 18 & 20 & 22 & 24 & 27 & 28 & 29 & 32 \\
\hline $\begin{array}{l}\text { Papiery dłużne pozostałych } \\
\text { sektorów (w bln USD) }\end{array}$ & 24 & 27 & 28 & 31 & 34 & 37 & 42 & 48 & 51 \\
\hline Sektor bankowy (w bln USD) & 34 & 36 & 38 & 40 & 43 & 46 & 51 & 56 & 61 \\
\hline
\end{tabular}

Źródło: Rozwój systemu finansowego w Polsce, Departament Systemu Finansowego NBP, Warszawa 1.12.2009, s. 2.

Tabela 2

Aktywa systemu finansowego w krajach Europy Środkowo-Wschodniej w relacji do PKB w latach 2005-2008 (w \%)

\begin{tabular}{|l|r|r|r|r|}
\hline Lata & 2005 & 2006 & 2007 & 2008 \\
\hline Polska & 85,0 & 96,5 & 103,2 & 110,5 \\
\hline Czechy & 126,7 & 125,6 & 134,3 & 137,3 \\
\hline Węgry & 114,9 & 128,4 & 140,5 & 152,4 \\
\hline Strefa euro (MU 15) & 419,8 & 442,7 & 465,3 & 456,4 \\
\hline
\end{tabular}

Źródło: jak do tab. 1, s. 3.

W ramach struktury systemu finansowego w Polsce dominują banki, których poziom aktywów wykazuje tendencję wzrostu. Można jednak zaobserwować tendencję zmniejszania się dominacji sektora bankowego w systemie bankowym w Polsce na rzecz otwartych funduszy emerytalnych i funduszy inwestycyjnych, co oznacza dezintermediację sektora bankowego, obecną w innych krajach europejskich. Kryzys na rynkach finansowych był widoczny w odniesieniu do funduszy inwestycyjnych, których poziom aktywów spadł w porównaniu do poprzedniego roku w 2007 i 2008, ale w dwóch pierwszych kwartałach 2009 wykazuje już tendencję wzrostu. Badając relacje aktywów funduszy inwestycyjnych do depozytów bankowych od sektora niefinansowego można zauważyć ich znaczne obniżenie z 32,4\% w roku 2006 do 15,2 w 2008 a następnie wzrost do poziomu 17,1 w drugim kwartale 2009 [Rozwój systemu...: 2009: 24]. Spadek 
wartości aktywów w porównaniu do poprzedniego roku jest także widoczny w odniesieniu do podmiotów maklerskich i otwartych funduszy emerytalnych.

Tabela 3

Aktywa systemu finansowego w Polsce w latach 2001-2009 (w mld zł)

\begin{tabular}{|l|r|r|r|r|r|r|r|r|r|}
\hline Lata & 2001 & 2002 & 2003 & 2004 & 2005 & 2006 & 2007 & 2008 & 2009 \\
\hline Banki komercyjne & 439,7 & 434,6 & 455,0 & 499,7 & 539,4 & 624,0 & 729,4 & 963,0 & 976,3 \\
\hline SKOKi & 30,0 & 31,9 & 34,0 & 38,8 & 47,1 & 57,8 & 65,6 & 75,8 & 76,2 \\
\hline Zakłady ubezpieczeniowe & 47,1 & 57,6 & 65,7 & 77,9 & 89,6 & 108,6 & 126,9 & 137,9 & 140,3 \\
\hline Fundusze inwestycyjne & 12,1 & 23,0 & 33,8 & 37,6 & 61,6 & 99,2 & 133,8 & 73,9 & 77,2 \\
\hline OFE & 19,4 & 31,6 & 44,8 & 62,6 & 86,1 & 116,6 & 140,0 & 138,3 & 152,9 \\
\hline Podmioty maklerskie & 2,9 & 2,8 & 3,7 & 5,5 & 6,9 & 10,8 & 11,8 & 8,6 & 9,6 \\
\hline Razem & 553,0 & 584,0 & 640,3 & 726,3 & 836,0 & 1023,0 & 1214,8 & 1407,0 & 1443,6 \\
\hline
\end{tabular}

Źródło: jak do tab. 1, s. 5.

Tabela 4

Charakterystyka liczbowa banków reprezentujących różne formy własności w Polsce w okresie 1996-2006

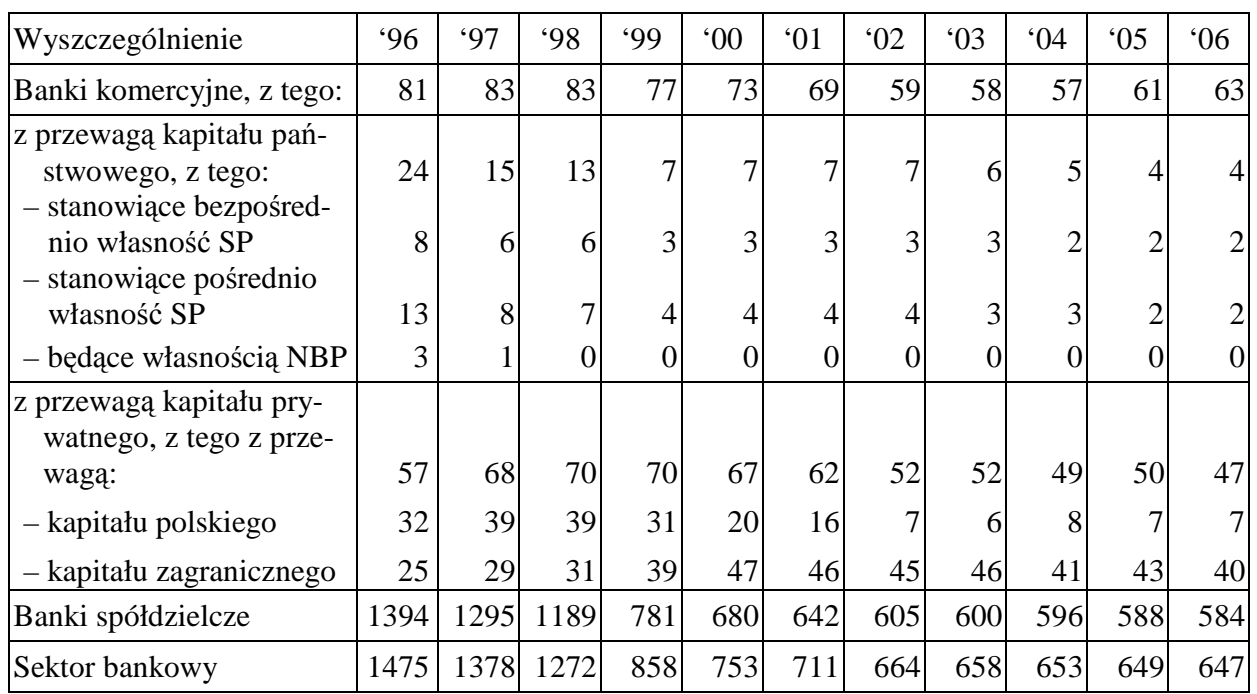

Źródło: Sytuacja finansowa banków w 2006, 2007, NBP, Warszawa. 
Analizując sektor bankowy można zauważyć oprócz powiększania się jego potencjału ekonomicznego spadek jego liczebności. W rezultacie procesów konsolidacyjnych, mających miejsce zwłaszcza w odniesieniu do sektora banków spółdzielczych nastapiło zmniejszanie liczby banków. Kolejną ważną tendencją rozwoju była rosnąca aktywność banków z kapitałem zagranicznym (zob. tab. 4). W ramach poszukiwania dróg rozwoju, rozszerzania oferty usług i zwiększania liczby potencjalnych klientów banki m. in. podjęły współpracę z firmami ubezpieczeniowymi.

Sektor bankowy jest bardzo ważnym segmentem systemu finansowego, odgrywającym wiele istotnych ról zarówno w zakresie mikro jak i makroekonomicznym. Jakość jego funkcjonowania ma istotne znaczenie dla stabilności całej gospodarki i jej zrównoważonego rozwoju. Banki powinny być aktywne, jako przedsiębiorstwa komercyjne, działające w interesie własnym i akcjonariuszy, poszukujące ekonomicznej efektywności, z drugiej strony zaś, razem z innymi pośrednikami na rynku finansowym, powinny budować zaufanie klientów w sferze moralno-etycznej. Według D. Korenik zadania banku na rzecz wzrostu dobrobytu mają polegać na: maksymalizacji oszczędności gospodarstw domowych i przedsiębiorstw, zarządzaniu ryzykiem, alokacji oszczędności krajowych i zagranicznych w inwestycje, monitorowaniu ładu korporacyjnego. W powyższym podejściu można dostrzec społeczną rolę systemu. Mając na uwadze powyższe rozważania warto zauważyć, że banki w swoim działaniu powinny kierować się nie tylko racjonalnymi przesłankami, ale także solidarnością i aspektem moralnym [Korenik: 2009: 14-17]. Bankom powinno zależeć nie tylko na krótkoterminowym zysku, ale na długoterminowych relacjach ze swoimi klientami. W tym kontekście coraz większego znaczenia nabierają prokonsumenckie przemiany na rynku usług bankowych.

\section{Znaczenie konsumenta dla rynku usług bankowych}

Ważną grupę klientów sektora bankowego stanowią konsumenci. Pojęcie konsumenta jest używane $\mathrm{w}$ różnych aspektach i może dotyczyć różnych elementów życia i dziedzin wiedzy. Człowiek funkcjonuje w wielu obszarach, jednym z nich jest wymiar ekonomiczny, co oznacza, że człowiek jest istotą gospodarująca, dąży do posiadania rożnego rodzaju dóbr i środków umożliwiających ich posiadanie. Człowiek występuje również w roli konsumenta [Janoś-Kresło, Mróz: 2006: 14]. Konsument w prawie polskim, w ustawie Kodeks Cywilny został zdefiniowany, jako osoba fizyczna dokonująca czynności prawnej niezwiązanej bezpośrednio z jej działalnością gospodarczą i zawodową ${ }^{1}$. Podobną definicję zawarto w Regulaminie Bankowego Arbitrażu Konsumenckiego, gdzie przyjęto, że konsumentem jest osoba fizyczna, zawierająca umowę z bankiem

\footnotetext{
${ }^{1}$ Ustawa z dnia 23 kwietnia 1964 r. Kodeks cywilny, DzU 1964, nr 16, poz. 93, art. 22.
} 
w celu niezwiązanym z działalnością gospodarczą ${ }^{2}$. Pojęcie konsumenta definiuje się w różny sposób. Zazwyczaj jednak jest ono odnoszone do osoby fizycznej zawierającej umowy w celu osobistym a nie komercyjnym [Łętowska: 2004: 4]. Często pojecie konsument jest definiowane jako podmiot ekonomiczny, zużywający nabyte usługi. W takim szerokim podejściu konsumentem może być osoba, grupa osób, przedsiębiorstwo, korzystające $\mathrm{z}$ wartości użytkowej produktów i usług. W niniejszym opracowaniu konsument będzie rozumiany jako osoba fizyczna, będąca finalnym nabywcą usług bankowych, powiązanych z ubezpieczeniowymi. W statystykach bankowych często kategoria klientów-konsumenci jest ujęta $\mathrm{W}$ szerszej grupie gospodarstwa domowe. W badaniach pojawia się również określenie konsument przeciętny oraz konsument masowy. W związku z niemożliwością określenia potrzeb klienta masowego pojawiła się koncepcja segmentacji rynku, polegająca na wyodrębnieniu grup konsumentów o podobnych cechach i potrzebach. W literaturze $\mathrm{z}$ zakresu marketingu pojawiają się jeszcze takie pojęcia jak: klient, nabywca, użytkownik. Klientem jest każdy podmiot ekonomiczny: osoba, gospodarstwo domowe, przedsiębiorstwo, instytucja, zainteresowany zakupem produktu, czy usługi. Nabywca natomiast kupuje produkty, chociaż niekoniecznie musi uczestniczyć w procesie podejmowania decyzji dotyczących zakupu i dana usługa nie musi być przeznaczona do użytkowania przez osobę go nabywającą. Z kolei użytkownik to osoba lub grupa osób niebiorąca bezpośredniego udziału w procesie zakupu [Janoś-Kresło, Mróz: 2006:15].

Znaczenie klientów, którymi są gospodarstwa domowe dla sektora bankowego w grupie sektora niefinansowego staje się coraz większe wobec kolejnej kategorii klientów, którymi są przedsiębiorstwa. W odniesieniu do kredytów bankowych udzielanych w okresie 2006-2009 można zauważyć trend wzrostowy udziału gospodarstw domowych. W przypadku depozytów sektora niefinansowego w latach 2006-2009 również gospodarstwa domowe stanowią dominująca grupę klientów bankowych (zob. tab. 5).

Także analizując powyższe relacje z perspektywy gospodarstw domowych widoczne jest duże znaczenie depozytów bankowych w strukturze ich aktywów finansowych, wobec pozostałych produktów oferowanych przez innych pośredników finansowych (zob. tab. 6). Struktura oszczędności gospodarstw domowych oraz ich skłonność do oszczędzania zależy od koniunktury na rynku, na którą składa się między innymi poziom stóp procentowych, kondycja rynku kapitałowego, wiedza finansowa oraz znajomość usług finansowych.

W analizowanym okresie 2005-2008 udział depozytów bankowych początkowo malał na rzecz większego zainteresowania inwestycjami $\mathrm{w}$ instrumenty rynku kapitałowego a następnie, w roku 2008 zwiększył się z powodu braku

\footnotetext{
${ }^{2}$ Regulamin Bankowego Arbitrażu Konsumenckiego, §1 punkt 2.
} 
stabilności na rynkach finansowych i poszukiwania bezpiecznych sposobów zagospodarowywania nadwyżek finansowych (patrz tab. 7).

Pomimo spadku udziału depozytów bankowych w strukturze aktywów finansowych gospodarstw domowych tempo ich przyrostu w okresie 2005-2008, z roku na rok rosło i chociaż było stosunkowo niewysokie charakteryzowała je stabilność w porównaniu z dynamiką innych inwestycji.

Tabela 5

Struktura kredytów i depozytów bankowych udzielanych przedsiębiorstwom i gospodarstwom domowym według stanów na koniec okresów (mln zł i \%)

\begin{tabular}{|c|c|c|c|c|c|c|c|c|}
\hline \multirow{2}{*}{ Wyszczególnienie } & \multicolumn{2}{|c|}{$12 / 2006$} & \multicolumn{2}{|c|}{$12 / 2007$} & \multicolumn{2}{|c|}{$12 / 2008$} & \multicolumn{2}{|c|}{$12 / 2009$} \\
\hline & $\operatorname{mln} \mathrm{zł}$ & $\%$ & $\mathrm{mln} \mathrm{zł}$ & $\%$ & $\mathrm{mln} \mathrm{zł}$ & $\%$ & $\mathrm{mln} \mathrm{zł}$ & $\%$ \\
\hline $\begin{array}{l}\text { Kredyty dla sektora niefinan- } \\
\text { sowego }\end{array}$ & \multicolumn{2}{|c|}{322775} & \multicolumn{2}{|c|}{427543} & \multicolumn{2}{|c|}{593379} & \multicolumn{2}{|c|}{627898} \\
\hline przedsiębiorstw & 138346 & 42,9 & 171714 & 40,2 & 222562 & 37,5 & 212712 & 33,9 \\
\hline gospodarstw domowych & 183422 & 56,8 & 254202 & 59,1 & 368578 & 62,1 & 412470 & 65,7 \\
\hline $\begin{array}{l}\text { Depozyty dla sektora niefinan- } \\
\text { sowego }\end{array}$ & \multicolumn{2}{|c|}{375571} & \multicolumn{2}{|c|}{419308} & \multicolumn{2}{|c|}{494052} & \multicolumn{2}{|c|}{560049} \\
\hline przedsiębiorstw & 125886 & 33,5 & 144809 & 34,5 & 149099 & 30,2 & 166028 & 29,6 \\
\hline gospodarstw domowych & 238818 & 63,6 & 262400 & 62,6 & 330762 & 66,9 & 379671 & 67,8 \\
\hline
\end{tabular}

Źródło: obliczenia własne na podstawie: Podstawowe dane dotyczqce sektora bankowego w latach 2007-2009, KNF.

Struktura wybranych pozycji aktywów finansowych gospodarstw domowych według stanu na koniec okresów

\begin{tabular}{|l|r|r|r|r|}
\hline \multicolumn{1}{|c|}{ Udział w aktywach } & 2005 & 2006 & 2007 & 2008 \\
\hline Depozyty bankowe & $\mathbf{4 2 , 9}$ & $\mathbf{3 7 , 2}$ & $\mathbf{3 4 , 7}$ & $\mathbf{4 4 , 4}$ \\
\hline Środki na rachunkach OFE & 16,9 & 18,3 & 18,6 & 18,7 \\
\hline Tytuły uczestnictwa funduszy inwestycyjnych & 11,4 & 14,8 & 17,1 & 8,3 \\
\hline $\begin{array}{l}\text { Tytuły uczestnictwa ubezpieczeniowych funduszy kapitałowych } \\
\text { i składki oszczędnościowe ubezpieczeń na życie }\end{array}$ & 8,2 & 8,3 & 8,4 & 9,2 \\
\hline Akcje & 5,1 & 7,2 & 8,1 & 3,8 \\
\hline Skarbowe papiery wartościowe & 3,3 & 2,0 & 1,4 & 1,8 \\
\hline Depozyty w SKOK & 1,0 & 0,9 & 0,9 & 1,2 \\
\hline Gotówka w obiegu (bez kas banków) & 11,2 & 10,8 & 10,3 & 12,3 \\
\hline
\end{tabular}

Źródło: Rozwój systemu finansowego w Polsce, Departament Systemu Finansowego NBP, Warszawa 1.12.2009, s. 13. 
Dynamika (r/r) wybranych pozycji aktywów finansowych gospodarstw domowych według stanu na koniec okresów

\begin{tabular}{|l|r|r|r|r|}
\hline \multicolumn{1}{|c|}{ Tempo przyrostu (r/r, w \%) } & 2005 & 2006 & 2007 & 2008 \\
\hline Aktywa finansowe ogółem & 17,1 & 25,0 & 18,0 & $-1,5$ \\
\hline Depozyty bankowe & $\mathbf{5 , 4}$ & $\mathbf{8 , 6}$ & $\mathbf{9 , 9}$ & $\mathbf{2 6 , 0}$ \\
\hline Środki na rachunkach OFE & 37,5 & 35,4 & 20,1 & $-1,2$ \\
\hline Tytuły uczestnictwa funduszy inwestycyjnych & 67,7 & 62,5 & 36,6 & $-52,1$ \\
\hline $\begin{array}{l}\text { Tytuły uczestnictwa ubezpieczeniowych funduszy kapitało- } \\
\text { wych i składki oszczędnościowe ubezpieczeń na życie }\end{array}$ & 18,6 & 26,8 & 18,9 & 7,5 \\
\hline Akcje & 36,8 & 78,0 & 33,3 & $-54,4$ \\
\hline Skarbowe papiery wartościowe & $-17,2$ & $-23,7$ & $-16,8$ & 26,3 \\
\hline Depozyty w SKOK & 26,7 & 11,3 & 20,7 & 28,3 \\
\hline Gotówka w obiegu (bez kas banków) & 12,6 & 20,3 & 12,3 & 17,5 \\
\hline
\end{tabular}

Źródło: jak do tab. 6.

\section{Rozwój współpracy bankowo-ubezpieczeniowej}

Zabiegając o pozyskanie nowych i dostarczenie dotychczasowym klientom usług coraz lepiej spełniających oczekiwania, a także licząc na wymierne i niewymierne korzyści, lepsze wykorzystanie sieci placówek bankowych i wzrost zysków, banki rozpoczęły współpracę z sektorem ubezpieczeniowym. W rezultacie tej współpracy klienci uzyskują korzyści w postaci dostępu do kilku produktów jednocześnie oraz możliwość pozyskania połączonych produktów po niższych cenach niż w przypadku nabywania ich oddzielnie.

Wyjaśniając czynniki warunkujące decyzje banków o współpracy z sektorem ubezpieczeń życiowych powoływano się na: zmiany demograficzne, środowisko ekonomiczne, kierunki oszczędzania, zróżnicowane podejście do podatków, tendencje rozwojowe sektora ubezpieczeniowego. W ramach czynników demograficznych zwracano uwagę na: wzrost populacji, starzenie się społeczeństwa, pragnienie zachowania poprzednich standardów życiowych po przejściu na emeryturę. Istotne znaczenie dla zakupu ubezpieczenia na życie ma także zaufanie społeczne do publicznych systemów zabezpieczeń emerytalnych, które nie gwarantują w pełni satysfakcjonującej stabilizacji finansowej po przejściu na emeryturę.

Stopniowo ulegająca zmianie struktura klientów bankowych, znajduje wyraz m. in. w rozwoju bankowości detalicznej. Podjęcie takiej strategii działania powoduje wzrost gęstości sieci oddziałów detalicznych. Rozwój techniki informacyjnej pozwolił na segmentację klientów, wykorzystującą bazę danych. In- 
formacja o klientach stanowi jedną ze znaczących przewag konkurencyjnych banków, w porównaniu do firm ubezpieczeniowych. Banki poszukują sposobów, aby maksymalnie wykorzystać kosztowną sieć detaliczną. W ramach analizy produktów finansowych zauważono, że ubezpieczenia, a zwłaszcza ubezpieczenia na życie, generują potencjalny, wysoki zysk połączony ze stosunkowo niskim ryzykiem. Stad bardziej popularnym produktem współpracy są ubezpieczenia na życie, chociaż banki proponują także produkty ubezpieczeń majątkowych i samochodowych. Usługi z dziedziny ubezpieczeń na życie są najprostsze w obsłudze. Ponadto nie stwarzają źródła potencjalnego konfliktu w momencie egzekwowania pokrycia szkód, a w związku z tym nie mogą być przyczyną niezadowolenia ze wzajemnych kontaktów.

Tabela 8

Struktura dystrybucji ubezpieczeń w wybranych krajach CEA w 2007 r. (w \%)

\begin{tabular}{|c|c|c|c|c|c|c|c|c|c|c|}
\hline \multirow{2}{*}{ Kraje } & \multicolumn{2}{|c|}{$\begin{array}{c}\text { Sprzedaż } \\
\text { bezpośrednia }\end{array}$} & \multicolumn{2}{|c|}{ Agenci } & \multicolumn{2}{|c|}{ Brokerzy } & \multicolumn{2}{|c|}{ Bancassurance } & \multicolumn{2}{|c|}{$\begin{array}{c}\text { Pozostałe } \\
\text { kanały }\end{array}$} \\
\hline & $\begin{array}{c}\text { na } \\
\text { życie }\end{array}$ & $\begin{array}{l}\text { nie na } \\
\text { życie }\end{array}$ & $\begin{array}{c}\text { na } \\
\text { życie }\end{array}$ & $\begin{array}{l}\text { nie na } \\
\text { życie }\end{array}$ & $\begin{array}{c}\text { na } \\
\text { życie }\end{array}$ & $\begin{array}{l}\text { nie na } \\
\text { życie }\end{array}$ & $\begin{array}{c}\text { na } \\
\text { życie }\end{array}$ & $\begin{array}{c}\text { nie na } \\
\text { życie }\end{array}$ & $\begin{array}{c}\text { na } \\
\text { życie }\end{array}$ & $\begin{array}{l}\text { nie na } \\
\text { życie }\end{array}$ \\
\hline Austria & 20,5 & 37,7 & 4,7 & 13,2 & 15,6 & 37,4 & 53,7 & 4,7 & 5,5 & 7,1 \\
\hline Belgia & 19,7 & 20,0 & 4,1 & 10,1 & 33,4 & 62,6 & 42,7 & 6,1 & 0,1 & 1,2 \\
\hline Bułgaria & 17,4 & 29,0 & 62,8 & 42,3 & 19,8 & 28,7 & - & - & - & - \\
\hline Chorwacja & 34,7 & 69,8 & 42,7 & 20,3 & 0,4 & 2,3 & 18,7 & 1,0 & 3,5 & 6,6 \\
\hline Francja & 16,0 & 35,0 & 7,0 & 35,0 & 13,0 & 18,0 & 62,0 & 9,0 & 2,0 & 3,0 \\
\hline Hiszpania & 7,7 & 24,0 & 18,2 & 38,7 & 8,8 & 28,1 & 63,2 & 7,9 & 2,1 & 1,4 \\
\hline Irlandia & 48,9 & 40,7 & 10,2 & - & 40,9 & 59,3 & - & - & - & - \\
\hline Litwa & 8,0 & 44,0 & 31,0 & 18,0 & 13,0 & 36,0 & 48,0 & 2,0 & - & - \\
\hline Luksemburg & 2,7 & 35,0 & 15,8 & 40,0 & 1,9 & 24,6 & $\mathbf{7 9 , 7}$ & 0,4 & - & - \\
\hline Niderlandy & 28,0 & 55,0 & 57,0 & 37,0 & - & - & 15,0 & 8,0 & - & - \\
\hline Niemcy & 2,8 & 5,1 & 54,6 & 56,1 & 18,0 & 25,5 & 21,6 & 6,6 & 3,0 & 6,7 \\
\hline Polska & 27,3 & 22,1 & 42,9 & 59,2 & 2,4 & 14,2 & 23,4 & 1,4 & 4,0 & 3,1 \\
\hline Portugalia & 3,6 & 11,6 & 7,9 & 61,1 & 1,0 & 16,4 & 87,3 & 10,0 & 0,2 & 0,9 \\
\hline Słowacja & 2,6 & 8,1 & 78,7 & 48,4 & 18,8 & 43,5 & - & - & - & - \\
\hline Słowenia & 2,5 & 21,2 & 52,8 & 66,3 & 16,3 & 9,8 & 8,8 & 0,4 & 19,6 & 2,3 \\
\hline Turcja & 13,8 & 9,3 & 34,6 & 70,1 & 0,9 & 9,7 & 50,6 & 10,9 & - & - \\
\hline $\begin{array}{rr}\text { Wielka } & \text { Bry- } \\
\text { tania } & \\
\end{array}$ & 6,9 & 22,6 & 19,7 & 3,7 & 73,4 & 54,1 & - & 10,0 & - & 1,4 \\
\hline Włochy & 11,2 & 6,4 & 21,1 & 84,4 & 1,4 & 7,4 & 66,3 & 1,8 & - & - \\
\hline
\end{tabular}

Źródło: Polski rynek ubezpieczeniowy. Polish Insurance Market 2004-2008, 2009, GUS, Warszawa, s. 101. 
Jedną z najbardziej popularnych form współpracy bankowo-ubezpieczeniowej jest tzw. bancassurance polegające na wykorzystaniu banku, jako kanału dystrybucji produktów ubezpieczeniowych. Można zauważyć, że dystrybucja, polegająca w przypadku ochrony ubezpieczeniowej na dostarczaniu ochrony odpowiadającej potrzebom nabywcy w zakresie sposobu, czasu i ceny jest ważnym instrumentem oddziaływania na rynek i sposobem wpływania na decyzje dotyczące zakupu usług [Sangowski: 2001: 28]. W Polsce tego typu współpraca zaczęła się rozwijać w latach dziewięćdziesiątych a w innych krajach europejskich była popularna już od lat osiemdziesiątych. Wykorzystanie kanału bankowego do dystrybucji polis ubezpieczeniowych w wybranych krajach europejskich zostało przedstawione $\mathrm{w}$ tab. 8 .

Analiza informacji zawartych w tab. 8 potwierdza większą popularność współpracy bankowo-ubezpieczeniowej w odniesieniu do ubezpieczeń na życie niż w stosunku do ubezpieczeń majątkowych. Krajami, które w roku 2007 miały największy udział banków w dystrybucji ubezpieczeń były: Portugalia $(87,3)$; Luksemburg $(79,7)$; Hiszpania $(63,2)$; oraz Francja $(62,0)$. Poziom bancassurance w Polsce w tym czasie był stosunkowo niski, jednak z roku na rok wykazywał tendencję wzrostu (zob. tab. 9 i 10).

Tabela 9

Kanały dystrybucji ubezpieczeń na życie ogółem - składka przypisana brutto (w tys. zł)

\begin{tabular}{|c|c|c|c|c|}
\hline Wyszczególnienie & 2005 & 2006 & 2007 & 2008 \\
\hline Ogółem & 15323526 & 21108627 & 25509426 & 38985973 \\
\hline Sprzedaż bezpośrednia: & 5170149 & 5951766 & 6973392 & 8943846 \\
\hline przez pracowników & 5170111 & 5951719 & 6973096 & 8942642 \\
\hline przez Internet & 38 & 47 & 62 & 42 \\
\hline przez telefon & - & - & 233 & 1163 \\
\hline Agenci ubezpieczeniowi: & 8319399 & 1254550 & 16913241 & 28247084 \\
\hline osoby fizyczne & 3788369 & 4881136 & 5335400 & 4128973 \\
\hline osoby prawne: & 4495054 & 7610963 & 10424294 & 23451986 \\
\hline - banki & 2205800 & 4300760 & 5967947 & 17405226 \\
\hline$-\mathrm{SKOK}$ & - & 25783 & 52957 & 50934 \\
\hline - pozostałe osoby prawne & 2289255 & 3284420 & 4403391 & 5995828 \\
\hline podmioty bez osobowości prawnej & 35976 & 50401 & 1153547 & 666125 \\
\hline Brokerzy ubezpieczeniowi i reasekuracyjni: & 632305 & 728424 & 616423 & 610699 \\
\hline osoby fizyczne & 143290 & 199501 & 120460 & 108485 \\
\hline osoby prawne & 489014 & 528923 & 495964 & 502214 \\
\hline Inne kanały dystrybucji & 1201674 & 1885936 & 1006370 & 1184344 \\
\hline
\end{tabular}

Źródło: jak do tab. 8, s. 184. 
Tabela 10

Struktura kanałów dystrybucji ubezpieczeń na życie ogółem - składka przypisana brutto (w \%)

\begin{tabular}{|l|r|r|r|c|}
\hline \multicolumn{1}{|c|}{ Wyszczególnienie } & 2005 & 2006 & 2007 & 2008 \\
\hline \hline Ogółem & 100 & 100 & 100 & 100 \\
\hline \hline Sprzedaż bezpośrednia: & 33,74 & 28,20 & 27,34 & 22,94 \\
\hline przez pracowników & 33,74 & 28,20 & 27,34 & 22,94 \\
\hline przez Internet & 0,00 & 0,00 & 0,00 & 0,00 \\
\hline przez telefon & - & - & 0,00 & 0,00 \\
\hline \hline Agenci ubezpieczeniowi: & 54,29 & 5,94 & 66,30 & 72,45 \\
\hline osoby fizyczne & 24,72 & 23,12 & 20,92 & 10,59 \\
\hline osoby prawne: & 29,33 & 36,06 & 40,86 & 60,15 \\
\hline - banki & $\mathbf{1 4 , 3 9}$ & $\mathbf{2 0 , 3 7}$ & $\mathbf{2 3 , 4 0}$ & $\mathbf{4 4 , 6 4}$ \\
\hline - SKOK & - & 0,12 & 0,21 & 0,13 \\
\hline - pozostałe osoby prawne & 14,94 & 15,56 & 17,26 & 15,38 \\
\hline podmioty bez osobowości prawnej & 0,23 & 0,24 & 4,52 & 1,71 \\
\hline \hline Brokerzy ubezpieczeniowi i reasekuracyjni: & 4,13 & 3,45 & 2,42 & 1,57 \\
\hline osoby fizyczne & 0,94 & 0,95 & 0,47 & 0,28 \\
\hline osoby prawne & 3,19 & 2,51 & 1,94 & 1,29 \\
\hline \hline Inne kanały dystrybucji & 7,84 & 8,93 & 3,95 & 3,04 \\
\hline
\end{tabular}

Źródło: obliczenia własne na podstawie: Polski rynek ubezpieczeniowy. Polish Insurance Market 2004-2008, op. cit., s. 184.

W okresie 2005-2008 widoczna jest tendencja wzrostu wykorzystania kanału bankowego w celu dystrybucji polis ubezpieczeniowych, zwłaszcza w odniesieniu do ubezpieczeń na życie. O tej tendencji zadecydowała perspektywa obniżenia kosztów akwizycji, bardzo ważnych z punktu widzenia towarzystwa ubezpieczeniowego. Pomimo wykorzystywania bezpośrednich kanałów dystrybucji, opartych na sprzedaży przez etatowych pracowników zakładów ubezpieczeń, a także poprzez Internet, czy za pomocą kontaktu telefonicznego popularna jest dystrybucja pośrednia realizowana przez agentów, brokerów, a także banki. Pierwszym zakładem ubezpieczeń, który zastosował bancassurance w Polsce było Towarzystwo Ubezpieczeń na Życie i Reasekuracji Amplico Life SA współpracujące z bankiem Pekao SA a następnie Commercial Union SA, powiązane z WBK SA [Barańska: 2004: 8]. 


\section{Etyczny wymiar relacji między klientem a bankiem w odniesieniu do współpracy bankowo-ubezpieczeniowej}

Etyczny wymiar działalności jest ważny dla funkcjonowania i rozwoju sektora bankowego. Według słownika języka polskiego etyka to (...) ogót zasad, norm postępowania przyjętych $w$ danym okresie $i$ środowisku [Sobol: 2006: 198]. Etyka ma związek z moralnością, którą interpretuje się jako zgodność dziatań ludzkich z prawda $i$ dobrem [Sobol: 2006: 458]. Problemy o wymiarze etycznym w bankowości powinny być rozpatrywane w kontekście takich wartości jak: uczciwość i sprawiedliwość. Odnosząc etyczne aspekty do bankowości można zauważyć, że w Polsce coraz bardziej widoczny staje się trend do prokonsumenckich przemian, coraz większą uwagę przywiązuje się do ochrony konsumenta i wyrównywania dysproporcji siły rynkowej między nim i profesjonalnym usługodawcą. Przedmiotem ochrony jak podkreśla W. Szpringer jest rynkowa pozycja konsumenta a nie jego indywidualny interes [Szpringer: 1999: 19]. Relacje między klientem a bankiem nakazujące uwzględnianie interesu publicznego określone są $\mathrm{w}$ regulacjach prawnych, statutach oraz kodeksach etycznych. Dorobek w zakresie dbałości o etyczną stronę ubezpieczeń bankowych jest związany z:

- Raportem bancassurance, opracowanym przez RzU w 2007 r.;

- Rekomendacją dobrych praktyk na polskim rynku bancassurance w zakresie ubezpieczeń ochronnych powiązanych z produktami bankowymi, opracowaną przez ZBP, wdrażaną od 1 listopada 2009 r.

- Raportami opracowanymi przez UOKiK z kontroli wzorców umów: stosowanych przez przedsiębiorców zawierających umowy o korzystanie z kart płatniczych (08.2005), stosowanych przez zakłady ubezpieczeń (09.2006); reklam kredytów przedświątecznych stosowanych przez banki i skoki (12.2006); stosowanych w umowach rachunków bankowych (02.2008); stosowanych w umowach kredytów hipotecznych (05.2008); stosowanych w ubezpieczeniach na życie (01.2010).

Istotne dla ochrony konsumenta, również na rynku usług ubezpieczeń bankowych są także regulacje prawne takie jak:

- Ustawa z dnia 23 kwietnia 1964 r. Kodeks Cywilny3,

- Ustawa z dnia 17 listopada 1964 r. Kodeks Postępowania Cywilnego 4 ,

- Ustawa z dnia 20 lipca 2001 r. o kredycie konsumenckim5,

- Ustawa z dnia 27 lipca 2002 r. o szczególnych warunkach sprzedaży konsumenckiej oraz o zmianie Kodeksu Cywilnego ${ }^{6}$,

\footnotetext{
${ }^{3}$ DzU 1964, nr 16, poz. 93 ze zm.

${ }^{4}$ DzU 1964, nr 43, poz. 296 ze zm.

${ }^{5}$ DzU 2001, nr 100, poz.1081 ze zm.

${ }^{6} \mathrm{DzU}$ 2002, nr 141, poz. 1176, ze zm.
} 
- Ustawa z dnia 28 lipca 2005 r. o zmianie Ustawy Kodeks Postępowania Cywilnego ${ }^{7}$,

- Ustawa z dnia 16 lutego 2007 r. o ochronie konkurencji i konsumentów ${ }^{8}$,

- Ustawa z dnia 23 sierpnia 2007 r. o przeciwdziataniu nieuczciwym praktykom rynkowym?

Analizując etyczny wymiar współpracy bankowo-ubezpieczeniowej warto zwrócić uwagę na ubezpieczenia towarzyszące kredytom hipotecznym, związanym z finansowaniem nieruchomości mieszkaniowych przez konsumentów. Taka płaszczyzna rozważań wynika ze zróżnicowania ubezpieczeń dodawanych do tych kredytów, a także łączy się z wartością tych ubezpieczeń i w związku z tym uciążliwością ich finansowych konsekwencji.

Ubezpieczenie kredytu polega na zapewnieniu przez zakład ubezpieczeń pokrycia strat majątkowych, powstałych u kredytodawców, z powodu nieotrzymania od kredytobiorców w sytuacjach określonych w umowie ubezpieczenia należności za udzielony kredyt [Sangowski: 2001: 238]. Zakład ubezpieczeniowy zapewnia ochronę a ubezpieczającym może być zarówno kredytobiorca jak i bank udzielający kredytu [Holly: 2003: 185]. Ubezpieczenia dodawane do kredytów hipotecznych można w różny sposób uporządkować np., biorąc pod uwagę podmiotowy charakter relacji związanych z tym sposobem finansowania nieruchomości albo wykorzystując ich obligatoryjność, ewentualnie fakultatywność. Mając na uwadze pierwsze kryterium i odnosząc się do zakresu niniejszego opracowania można wskazać ubezpieczenia występujące $w$ relacjach ubezpieczycieli z kredytodawcami i ubezpieczycieli z kredytobiorcami [Jajuga, Krysiak: 2004: 294]. Ubezpieczenia skierowane wyłącznie do banków to ubezpieczenia pomostowe i ubezpieczenia wkładu własnego. Ubezpieczenie kredytu na okres przejściowy zabezpiecza wyłącznie bank, ale składka w jego przypadku jest uiszczana przez kredytobiorcę. Sposób naliczania składki wobec tego ubezpieczenia jest różny, to może być składka miesięczna, naliczana za rok z góry albo do czasu wpisania hipoteki do księgi wieczystej, podwyższająca marżę kredytu [Bednarek: 2007: 4]. Ubezpieczenie niskiego wkładu własnego kredytobiorcy, podobnie jak poprzednie, zabezpiecza interesy banku. Składkę również w tym przypadku płaci klient. Nie posiadając wymaganego wkładu kredytobiorca płaci stawkę za dany okres ubezpieczenia.

Ubezpieczenia występujące $\mathrm{w}$ relacjach ubezpieczyciel-kredytobiorca o charakterze obligatoryjnym to: ubezpieczenia od ognia i innych zdarzeń losowych i ubezpieczenia na życie. Natomiast ubezpieczenia dobrowolne to: ubezpieczenie od utraty pracy, ubezpieczenie od odpowiedzialności cywilnej, ubezpieczenie kredytów innych niż złotowe, ubezpieczenia od utraty wartości nieruchomości.

\footnotetext{
${ }^{7}$ DzU 2005, nr 178, poz. 1478 ze zm.

${ }^{8}$ DzU 2007, nr 50, poz. 331 ze zm.

${ }^{9}$ DzU 2007, nr 171, poz. 1206 ze zm.
} 
Przedstawiając mniej popularne rodzaje ubezpieczeń można odnotować, że ubezpieczenie od odpowiedzialności cywilnej i ochrony prawnej obejmuje odpowiedzialność cywilną za szkody wyrządzone osobom trzecim oraz pokrycie kosztów poniesionych w celu obrony swoich praw. Naprawienie wyrządzonych szkód bez polisy ubezpieczeniowej może spowodować utratę zdolności do spłaty kredytu. W przypadku, gdy bank proponuje zamianę prowizji na składkę ubezpieczeniową na rzecz powyższego ubezpieczenia jest to korzystne rozwiązanie dla klienta. Ubezpieczenie kredytów innych niż złotowe, dotyczy kredytów denominowanych i jego celem jest ochrona przed ryzykiem kursowym. Zdarzeniem ubezpieczeniowym jest sytuacja, gdy rata kredytu w obcej walucie przekroczy maksymalną ratę kredytu w złotych, którą był w stanie obsługiwać kredytobiorca $\mathrm{w}$ momencie zaciagania kredytu. Zadaniem ubezpieczyciela jest pokrycie różnicy w ratach w okresie ochronnym 12 lub 24 miesięcy. Ubezpieczenie od utraty wartości nieruchomości chroni przed skutkami spadku wartości nieruchomości, stanowiącej zabezpieczenie kredytu zwłaszcza w pierwszych kliku latach okresu kredytowania.

Bywa, że w ramach współpracy bankowo-ubezpieczeniowej banki wykorzystują swoją przewagę $\mathrm{w}$ dostępie do informacji, umiejętności w zarządzaniu ryzykiem i są nierzetelne, nieuczciwe, nie rozumieją i nie szanują interesu klientów, co przejawia się w narzucaniu konieczności przystąpienia do danego rodzaju ubezpieczenia, nakłaniają do wykorzystania niepotrzebnego produktu. Przykładem takich działań jest ubezpieczenie nieruchomości od pożaru i innych zdarzeń losowych wraz z cesją praw wynikających $\mathrm{z}$ polisy na bank. $\mathrm{Z}$ założenia umowa ubezpieczenia mienia ma być ochroną dla ubezpieczającego poprzez wypłatę świadczenia w momencie zajścia określonego w umowie wypadku. Jednak w praktyce odszkodowanie wypłacone przez towarzystwo ubezpieczeniowe zaliczane jest na rzecz spłaty zaciągniętego kredytu. W tym momencie klient posiada jedynie iluzoryczną ochronę ubezpieczeniową, która wpłynie na spłatę rat kredytu bankowego, ale nie zapewni mu pokrycia strat majątkowych ${ }^{10}$. Świadczenie w postaci ochrony ubezpieczeniowej w tym przypadku przypada bankowi. Taka konstrukcja oznacza wyłączenie klienta ze stosunku ubezpieczenia, czyli klient jest obciążony kosztami ubezpieczenia, ale umowę zawiera się na rzecz banku, co powoduje dodatkowe koszty dla klienta, bez rekompensaty w postaci ochrony ubezpieczeniowej. Może pojawiać się podejrzenie, że zawarte w umowach ubezpieczeniowych postanowienia są niekorzystne i pomimo nazwy produktu ochrona będzie iluzoryczna.

Kolejnym przykładem ubezpieczeń obowiązkowych chroniących interesy banku jest ubezpieczenie na życie czy ubezpieczenie pomostowe. W tych przypadkach składkę również opłaca klient a świadczenie w postaci ochrony ubezpieczeniowej uzyskuje bank. Problematyczne ze względów etycznych było wy-

${ }^{10}$ Podstawowe problemy bancassurance $w$ Polsce, 2007, Raport Rzecznika Ubezpieczonych, Warszawa, s. 29-30. 
stawianie polis ubezpieczeniowych osobom, których ochrona nie obejmowała ze względu na wiek.

Jeżeli weźmiemy pod uwagę sytuację, w której bank zamierza ubezpieczyć umowy kredytowe, wówczas powinien sam ponosić ciężar opłaty składki, a nie przerzucać go na klienta, ponieważ to bank właśnie otrzymuje świadczenie, którym jest ochrona ubezpieczeniowa. Ponadto bank, jako ubezpieczający, nie może wykonywać na rzecz zakładu ubezpieczeń świadczeń akwizycyjnych, likwidacyjnych ani otrzymywać prowizji dotyczących umów zawieranych przez bank, ponieważ wykonywałby je wobec samego siebie. Ten stan rzeczy może powodować proponowanie lub narzucanie klientom banku ochrony ubezpieczeniowej nieadekwatnej do ich potrzeb, co stanowi naruszenie interesów konsumentów usługi ubezpieczeniowej, ponieważ klient powinien uzyskać z ubezpieczenia rzeczywistą korzyść. Także w praktyce banki otrzymują prowizję od ubezpieczycieli z tytułu składki, którą formalnie powinny płacić, ale która pochodzi z opłat wnoszonych od ubezpieczonych klientów banku, czyli ubezpieczający otrzymują prowizję, jako wynagrodzenie za zawarcie przez siebie umowy ${ }^{11}$.

W celu wykrycia nieprawidłowości i wyeliminowania z obrotu niekorzystnych dla konsumentów postanowień Urząd Ochrony Konkurencji i Konsumentów w 2008 r. przygotował raport, w którym dokonano analizy zgodności z obowiązującymi przepisami prawa wzorców umów kredytów hipotecznych, regulaminów, Tabel Opłat i Prowizji oraz umów ubezpieczenia ${ }^{12}$. Przedmiotem badań były jedynie umowy kredytu hipotecznego zawierane $\mathrm{z}$ konsumentami. W przypadku tych, których wartość nie przekraczała 80 tys. zł powinny być stosowane przepisy ustawy o kredycie konsumenckim, dającej kredytobiorcom szerszy zakres uprawnień np. prawo do wcześniejszej spłaty kredytu, prawo do informacji o wysokości całkowitego kosztu kredytu oraz wysokości rzeczywistej rocznej stopy oprocentowania. W raporcie odnoszono się do oceny abuzywności klauzul (klauzul niedozwolonych), które po uznaniu przez Sąd Ochrony Konkurencji i Konsumentów zostają wpisane do rejestru i od tego momentu ich stosowanie w obrocie $z$ konsumentami jest zakazane ${ }^{13}$. Prezes Urzędu OKiK wydaje

${ }^{11}$ Raport Bancassurance, 2008, Rzecznik Ubezpieczonych, Warszawa oraz I. D. Czechowska, 2008, Bezpieczeństwo klienta w procesach integracji sektora bankowego z sektorem ubezpieczeń, [w:] J. Nowakowski, T. Famulska (red.), Stabilność i bezpieczeństwo systemu bankowego, Difin, Warszawa, s. 129-138.

${ }^{12}$ Raport z kontroli wzorców umownych kredytów hipotecznych, 2008, UOKiK, Warszawa, maj.

${ }^{13}$ J. Zakolska, 2007, Niedozwolone postanowienia umowne w ogólnych warunkach ubezpieczeń w świetle obserwacji Rzecznika Ubezpieczonych oraz Komisji Nadzoru Ubezpieczeń i Funduszy Emerytalnych, „Rozprawy Ubezpieczeniowe”, Z. 1(2), s. 25-34; P. Wawszczak, 2008, Stosowanie klauzul abuzywnych, jako praktyka naruszajaca zbiorowe interesy konsumentów, „Monitor Ubezpieczeniowy”, nr 36, grudzień, s. 32-35; M. P. Ziemiak, 2008, Klauzule abuzywne w polskim obrocie ubezpieczeniowym. Ocena mechanizmów ochrony konsumenta w Polsce na tle rozwiqzań niemieckich i francuskich, „Rozprawy Ubezpieczeniowe”, Z. 4(1), s. 97-108; R. Stefanicki, 2009, 
decyzje stwierdzające stosowanie praktyki naruszające zbiorowe interesy konsumentów i nakazuje zakazanie ich stosowania. Może również nałożyć karę pieniężną na przedsiębiorcę stosującego praktyki naruszające zbiorowe interesy konsumentów, do wysokości $10 \%$ przychodu osiagniętego w roku rozliczeniowym, poprzedzającym rok nałożenia kary. Autorzy raportu zajmowali się również analizą kwestionowanych, problematycznych zapisów, wątpliwych pod względem etycznym, dotyczących m. in. ubezpieczenia kredytu hipotecznego, takich jak ${ }^{14}$ :

- Obowiazku ponoszenia przez konsumentów kosztów umów ubezpieczenia zawieranych przez i na rzecz banku ${ }^{15}$,

- Obowiazku ustanowienia weksla wtasnego in blanco na zabezpieczenie roszczeń zakładu ubezpieczeń ${ }^{16}$,

- Uprawnień towarzystwa ubezpieczeniowego do prowadzenia działań regresowych $w$ przypadku wyptacenia bankowi odszkodowania z tytułu ubezpieczenia $^{17}$,

- Postanowień zgodnie z którymi koszt ubezpieczenia nie podlega zwrotowi za niewykorzystany okres ubezpieczenia ${ }^{18}$,

- Uprawnienia towarzystwa ubezpieczeniowego do weryfikacji autentyczności dokumentów tożsamości oraz weryfikacji autentyczności i prawdziwości dokumentów stanowiqcych podstawę ustalenia zdolności kredytowej ${ }^{19}$.

\section{Podsumowanie}

Współpraca bankowo-ubezpieczeniowa rozwija się dynamicznie. Głównym segmentem tego rynku jest sprzedaż i wykonanie umów ubezpieczenia zawiera-

Nieuczciwe praktyki rynkowe ubezpieczycieli zakazane w każdych okolicznościach na wybranych przyktadach „czarnej listy”, „Rozprawy Ubezpieczeniowe”, Z. 6(1), s. 7-17.

${ }^{14}$ Raport z kontroli wzorców ..., s. 37-40.

${ }^{15}$ Uznano, że nie ma żadnych podstaw, aby kredytobiorca ponosił koszty umów ubezpieczenia zawieranych przez bank, który działa na swoją rzecz, w sytuacji, gdy kredytobiorca nie jest stroną tej umowy ani też uposażonym. Jednak kredytobiorca pozostaje osobą trzecią i nie tylko nie odnosi żadnych korzyści z umowy, która zabezpiecza bank, ale ponosi odpowiedzialność regresową.

${ }^{16} \mathrm{Nie}$ ma żadnego uzasadnienia do tego by kredytobiorca był zobowiązany do wystawienie ww. weksla, jeżeli wskazane umowy ubezpieczenia zawierane są przez bank, który działa na swoją rzecz, a kredytobiorca nie jest stroną tych umów ani też uposażonym z umów.

${ }^{17}$ Konsument, jako osoba trzecia, która ponosi koszty umowy, nie tylko nie odnosi żadnych korzyści z umowy, która zabezpiecza bank, ale ponosi dodatkowo odpowiedzialność regresową.

${ }^{18}$ Art. $813 \$ 1$ Kodeksu cywilnego stanowi, że składkę ubezpieczeniową oblicza się za cały czas trwania odpowiedzialności ubezpieczyciela. Niedozwolone jest jej pobieranie za okres, w którym zakład nie ponosi odpowiedzialności.

${ }^{19}$ Powyższe postanowienie przyznaje towarzystwu ubezpieczeń bardzo szeroki zakres uprawnień. Stanowi dla kredytobiorcy dużą uciążliwość zarówno ze względu na czasochłonność, jak i koszty uzyskania. Za autentyczność tych dokumentów odpowiada bank. 
nych głównie za pośrednictwem banków na rzecz kredytobiorców. Rośnie również liczba niezadowolonych konsumentów $\mathrm{m}$. in. dlatego że często ubezpieczenia te mają wąski zakres ochrony, ale duży obszar wyłączeń a także występują w nich niezrozumiałe, nieprecyzyjne pojęcia. Konsumenci mają poza tym ograniczone możliwości wyboru ubezpieczenia właściwego. Problem polega również na dostosowaniu ochrony ubezpieczeniowej do potrzeb (kiedy konsumentowi zależy na uzyskaniu kredytu jest gotowy na przyjęcie różnych warunków również przystapienia do ubezpieczenia [Olendzka: 2009: 9]) oraz sposobu jej finansowania. Przyczyny tych zjawisk wynikają zarówno ze stosunkowo niskiej świadomości ubezpieczeniowej konsumentów, nienależytego informowania o warunkach ubezpieczenia, niewłaściwego szkolenia personelu jak i braku odpowiedniego nadzoru. Przypadki naruszenia interesów konsumentów ubezpieczeń bankowych są zgłaszane do Bankowego Arbitrażu, Rzecznika Ubezpieczonych, Urzędu Ochrony Konkurencji i Konsumentów a także do Sądu Polubownego przy Komisji Nadzoru Finansowego oraz do powiatowych Rzeczników Konsumentów. Pomimo wielu zastrzeżeń widoczne są również pozytywne zmiany w obsłudze umów ubezpieczenia, i chociaż branża ubezpieczeniowa nie przyjęła Dobrych Praktyk jakość świadczonych usług jest coraz lepsza. Wydaje się np., że definitywnie rozwiązano problem odzyskania części składki przez konsumentów spłacających wcześniej kredyt. Ustalono m. in. w Rekomendacji, że klient ma zawsze prawo do rezygnacji z ochrony ubezpieczeniowej przed upływem okresu ubezpieczenia. RzU stwierdził także, że zgodnie z przepisem art. 813 Ustawy z dnia 23 kwietnia 1964 r. Kodeks cywilny, składkę oblicza się za czas trwania odpowiedzialności ubezpieczyciela. W przypadku wygaśnięcia stosunku ubezpieczenia przed upływem okresu, na jaki została zawarta umowa ubezpieczającemu przysługuje zwrot składki za okres niewykorzystanej ochrony ubezpieczeniowej ${ }^{20}$ a bank nie może pobierać żadnych opłat manipulacyjnych związanych $\mathrm{z}$ odstapieniem od umowy ubezpieczenia. Na bankach natomiast obecnie spoczywa obowiązek informowania o warunkach ubezpieczenia, sprawdzania czy dany konsument spełnia wymogi ubezpieczenia i czy ubezpieczenie odpowiada jego potrzebom. Również do zadań banku należy przekazywanie konsumentom informacji na temat zgłaszania roszczeń i prezentacja informacji o procedurach likwidacji szkody. Takie obowiązki powinny obligować banki do monitorowania wykonania umowy i badania liczby zasadności decyzji odmawiających wypłaty świadczenia ubezpieczeniowego, co wydaje się pozytywnie wpłynąc na ochronę konsumenta na tym rynku. Podsumowując można zauważyć, że sytuacja pod względem etyczności działań na rynku ubezpieczeń bankowych zmieniła się na lepsze, ale jest jeszcze sporo do zrobienia, wątpliwości na

${ }^{20}$ M. Więcko, 2009, Zwrot składki ubezpieczeniowej w przypadku wcześniejszej sptaty kredytu, „Monitor Ubezpieczeniowy”, nr 38, czerwiec, s. 32-33; M. Więcko, 2010, Działania Rzecznika Ubezpieczonych na rzecz ochrony konsumentów zawierajacych umowy ubezpieczenia w bankach, „Monitor Ubezpieczeniowy”, nr 41, marzec, s. 26-29. 
przykład budzą stosunkowo wysokie koszty tych ubezpieczeń. Nadzieję na wzrost aktywności w wykorzystaniu etycznych działań budzi fakt, że są one ekonomicznie uzasadnione, chociażby dlatego, że mogą wpłynąć pozytywnie na poprawę wizerunku zarówno banków jak i firm ubezpieczeniowych, a przez to na stabilność systemu finansowego i całej gospodarki.

\section{Bibliografia:}

Barańska Janina, 2004, Polisa i kredyt pod jednym dachem, „Gazeta Ubezpieczeniowa", nr 15.

Bednarek Maciej, 2007, Kredyt bez polisy oferuja trzy banki, „Gazeta Prawna”, wrzesień.

Czechowska Iwona Dorota, 2008, Bezpieczeństwo klienta w procesach integracji sektora bankowego z sektorem ubezpieczeń, [w:] J. Nowakowski, T. Famulska (red.), Stabilność i bezpieczeństwo systemu bankowego, Difin, Warszawa.

Holly Romuald, 2003, Ubezpieczenia finansowe $i$ gwarancje ubezpieczeniowe, Poltext, Warszawa.

Jajuga Krzysztof, Krysiak Zbigniew, 2004, Ryzyko kredytowe wierzytelności hipotecznych - modelowanie $i$ zarzadzanie, ZBP, Warszawa.

Janoś-Kresło Mirosława, Mróz Bogdan (red.), 2006, Konsument i konsumpcja we współczesnej gospodarce, Szkoła Główna Handlowa w Warszawie, Warszawa.

Korenik Dorota, 2009, O roli stużebnej banków komercyjnych, Wydawnictwo Uniwersytetu Ekonomicznego we Wrocławiu, Wrocław.

Łętowska Elżbieta, 2004, Europejskie prawo umów konsumenckich, C. H. Beck, Warszawa.

Olendzka Halina, 2009, Etyka na rynku ubezpieczeń w Polsce z perspektywy Rzecznika Ubezpieczonych, „Monitor Ubezpieczeniowy”, nr 40, grudzień.

Podstawowe problemy bancassurance w Polsce, 2007, Raport Rzecznika Ubezpieczonych, Warszawa.

Polski rynek ubezpieczeniowy. Polish Insurance Market 2004-2008, 2009, GUS, Warszawa.

Raport z kontroli wzorców umownych kredytów hipotecznych, 2008, UOKiK, Warszawa.

Regulamin Bankowego Arbitrażu Konsumenckiego.

Rozwój systemu finansowego w Polsce, 2007, Departament Systemu Finansowego NBP, Warszawa.

Sangowski Tadeusz, 2001, Ubezpieczenia gospodarcze, Poltext, Warszawa.

Sobol Elżbieta (red.), 2006, Stownik języka polskiego, PWN, Warszawa. 
Stefanicki Robert, 2009, Nieuczciwe praktyki rynkowe ubezpieczycieli zakazane w każdych okolicznościach na wybranych przykładach „czarnej listy”, „Rozprawy Ubezpieczeniowe”, Z. 6(1).

Sytuacja finansowa banków w 2006, 2007, 2007-2008, NBP, Warszawa.

Szpringer Wojciech, 1999, Ochrona klienta ustug bankowych w Unii Europejskiej $i$ w Polsce, Twigger, Warszawa.

Wawszczak Paweł, 2008, Stosowanie klauzul abuzywnych, jako praktyka naruszajaca zbiorowe interesy konsumentów, „Monitor Ubezpieczeniowy”, nr 36, grudzień.

Więcko Małgorzata, 2009, Zwrot sktadki ubezpieczeniowej w przypadku wcześniejszej spłaty kredytu, „Monitor Ubezpieczeniowy”, nr 38, czerwiec.

Więcko Małgorzata, 2010, Działania Rzecznika Ubezpieczonych na rzecz ochrony konsumentów zawierajacych umowy ubezpieczenia $w$ bankach, „Monitor Ubezpieczeniowy”, nr 41, marzec.

Witkowska Justyna, 2008, Kanaty dystrybucji ustug ubezpieczeniowych, Wydawnictwo Dom Organizatora, Toruń.

Zakolska Joanna, 2007, Niedozwolone postanowienia umowne w ogólnych warunkach ubezpieczeń w świetle obserwacji Rzecznika Ubezpieczonych oraz Komisji Nadzoru Ubezpieczeń i Funduszy Emerytalnych, „Rozprawy Ubezpieczeniowe", Z. 1(2).

Ziemiak Michał, Piotr, 2008, Klauzule abuzywne w polskim obrocie ubezpieczeniowym. Ocena mechanizmów ochrony konsumenta w Polsce na tle rozwiqzań niemieckich i francuskich, „,Rozprawy Ubezpieczeniowe”, Z. 4(1).

\title{
ETHICS IN BANKING IN RELATION TO THE COOPERATION WITH INSURANCE SECTOR
}

\begin{abstract}
Summary
The customers, their behavior on the market, reasons for undertaken actions and decisions have a great role in functioning and economical development. However, the customers are often treated inappropriately by professional service. There was presented a problematic of clients protection's system, who are customers on the banking market services connected with insurances, mortgage credits and ethic problems. The domination of banking sector on the finance market and also the role of customers as an important clients group of this sector was taken under consideration. The topic is wide, multithreading, up to date and controversial too.
\end{abstract}

Key words: ethics, ethics in banking, customers, insurance sector. 